\title{
Electrospun carbon nanofibers loaded with spinel-type cobalt oxide as bifunctional catalysts for enhanced oxygen electrocatalysis
}

\author{
C. Alegre ${ }^{* 1,2}$, C. Busacca ${ }^{1}$, A. Di Blasi ${ }^{1}$, O. Di Blasi ${ }^{1}$, A.S. Aricò ${ }^{1}$, V. Antonucci ${ }^{1}$, E. \\ Modica $^{1}$, V. Baglio*1 \\ ${ }^{1}$ Institute for Advanced Energy Technologies (ITAE) “Nicola Giordano”, CNR-ITAE, \\ Salita S. Lucia sopra Contesse, 5, 98126, Messina (Italy) \\ ${ }^{2}$ Laboratory of Research in Fluid Dynamics and Combustion Technologies, LIFTEC, CSIC- \\ University of Zaragoza, C/. Maria de Luna 10, 50018 - Zaragoza (Spain) \\ *corresponding authors: $\underline{\text { alegre@litec.csic.es ; vincenzo.baglio@itae.cnr.it }}$
}

\begin{abstract}
The electrocatalysis of oxygen in alkaline media is a challenging issue, influencing the performance of many electrochemical devices: fuel cells, unitized regenerative fuel cells, electrolyzers and metal-air batteries. This new manuscript proposes the synthesis of graphitic carbon nanofibers obtained by electrospinning with a cobalt-based spinel oxide, $\mathrm{Co}_{3} \mathrm{O}_{4} / \mathrm{CNF}$. By means of a simple, reproducible and scalable method, a bifunctional catalyst with a promising performance is obtained, being able of carrying out the electrocatalysis of oxygen (oxidation of water, evolution and reduction of oxygen) in a basic solution. The combination of the active species on cobalt oxide $\left(\mathrm{Co}^{2+}, \mathrm{Co}^{3+}\right.$ and $\mathrm{Co}-$ $\mathrm{N}_{\mathrm{x}}$ ), along with active species in the carbon nanofiber (graphitic and pyridinic $\mathrm{N}$ ), gives rise to a catalyst with a remarkable reversibility (difference between Ehalf-wave-potential (reduction) and $\mathrm{E}_{10 \mathrm{~mA} / \mathrm{cm} 2}($ evolution)): $\Delta \mathrm{E}=790 \mathrm{mV}$ ), a low over-potential for the evolution of oxygen $(\eta=416 \mathrm{mV})$ and $959 \mathrm{mV}$ of oxygen reduction onset potential, equal to that of a benchmark catalyst, $\mathrm{Pt} / \mathrm{C}$.
\end{abstract}

Keywords: bifunctional air electrodes, oxygen reduction; oxygen evolution; spinel; electrospinning. 


\section{Introduction}

Research on bi-functional catalysts for air electrodes, i.e, positive electrodes in metal-air batteries is continuously increasing [1-10]. Metal-air batteries (MABs), operating in alkaline media and using $\mathrm{Zn}, \mathrm{Fe}, \mathrm{Mg}$, etc. at the negative electrode, present promising features in comparison to conventional lithium-ion batteries, such as high energy densities, low cost (since abundant materials are used) as well as environmental safety [11-18]. Air electrodes take oxygen from the air, making these batteries extraordinary light, another advantage in comparison to conventional ones. However, the development of these devices has been hindered by the lack of a stable and efficient bifunctional catalyst for the air electrode. In fact, the electrocatalysis of oxygen is very challenging, given that the air electrode must be both active and long-lasting for both the oxidation of water, also called oxygen evolution (shorten as OER), which proceeds when a battery is charged, and the reduction of oxygen (shorten as ORR), occurring on discharging. The ability of the bifunctional catalyst to carry out these two reactions determines the electrochemical performance of the battery $[1,15,17,19,20]$.

Oxides based on transition metals have been widely investigated for their role as bifunctional materials $[2,3,25,26,4,5,7,9,21-24]$, being cobalt-based oxides the most active catalysts for the electrocatalysis of oxygen $[8,27,36,37,28-35]$. Co-based oxides are interesting as bifunctional materials for oxygen reactions thanks to their low cost, ample stability and suitable performance for the OER and ORR [4,27,38-40]. On the contrary, these oxides present a relatively small surface area and a poor electrical conductivity. For these reasons, usually combining them with carbon nanostructures is desirable for achieving a catalytic activity close to the benchmark catalysts, i.e. precious metals. One way of promoting catalytic activity and stability is by designing tailored composite carbon-based bifunctional catalysts with particular geometries $[1,9,41]$. Yet, 
under corrosive (high potentials) conditions occurring during charging of MABs, durability of carbon-based materials is a challenge that must be still further improved [42]. The use of nanostructured carbonaceous structures like carbon nanowires, carbon nanotubes/nanofibers could alleviate this issue, since they present an enhanced resistance towards corrosion compared to other carbons [43-48]. For the preparation of these materials, the electrospinning technique is recognized as a fast and efficient way. This method is also useful for producing active metals supported on carbon nanofibers (CNFs) $[49,50]$. Recently, in our laboratories, $\mathrm{CNFs}$ modified with cobalt $\left(\mathrm{Co}^{0}\right.$ and $\left.\mathrm{Co}^{2+}\right), \mathrm{CoO}-$ $\mathrm{Co} / \mathrm{CNF}$, were prepared by electrospinning and tested as air electrodes. The stability and reversibility (meaning bifunctionality) of the $\mathrm{Co}^{0}-\mathrm{Co}^{2+}$ system were remarkable [51]. In the present work, the latter catalyst, after the electrospinning preparation, has been oxidized with the aim of synthesizing the pure spinel structure $\left(\mathrm{Co}_{3} \mathrm{O}_{4}\right)$ supported on CNFs. The electrochemical behavior of the Co-based spinel has been compared with the previously developed $\mathrm{CoOCo} / \mathrm{CNF}$ to elucidate the catalytic activity of the two systems for ORR and OER in relation with their physico-chemical properties.

\section{Experimental}

\subsection{Preparation of electrospun $\mathrm{CNF}$ with cobalt-oxide}

$\mathrm{Co}_{3} \mathrm{O}_{4} / \mathrm{CNF}$ was prepared as in a previous paper [51]. A further step was added, consisting on a treatment in air at $350{ }^{\circ} \mathrm{C}(30 \mathrm{~min})$ inside a tube furnace in order to obtain the spinel phase $\left(\mathrm{Co}_{3} \mathrm{O}_{4}\right)$ for the cobalt species. The product was denoted as $\mathrm{Co}_{3} \mathrm{O}_{4} / \mathrm{CNF}$.

\subsection{Solid-state characterization}

$\mathrm{Co}_{3} \mathrm{O}_{4} / \mathrm{CNF}$ was characterized by several solid-state characterization techniques: Thermogravimetry in air, X-Ray Photoelectron spectroscopy, X-Ray diffraction, 
transmission electron microscopy and nitrogen physisorption. Details on techniques can be found in reference [52].

\subsection{Electro-catalytic activity evaluation}

The electro-catalytic activity of the spinel-type cobalt oxide on electrospun nanofibers was determined by electrochemical measurements performed in two different systems: rotating disk and gas-diffusion electrodes. Details on these techniques can be found in previous papers of our group [51-54]. $\mathrm{Co}_{3} \mathrm{O}_{4}$ was compared with a $\mathrm{CoO}-\mathrm{Co} / \mathrm{CNF}$, from a previous work [51], and with Pt- and Ir-based materials, as benchmark catalysts. $\mathrm{Pt} / \mathrm{Vulcan}$ and $\mathrm{IrO}_{2}$ were obtained as described in detail in [42] and in [55], respectively. The catalyst loading was the same for all the catalysts: $50 \mu \mathrm{g} \mathrm{cm}^{-2}$ for RDE measurements, $0.5 \pm 0.02 \mathrm{mg} \mathrm{cm}^{-2}$ for GDE measurements. In all cases, Nafion content was $30 \mathrm{wt} . \%$ of the ink.

\section{Results and discussion}

\subsection{Physico-chemical features}

In order to identify the suitable oxidation temperature to obtain a well-defined $\mathrm{Co}_{3} \mathrm{O}_{4}$ spinel structure, the TGA and DSC analyses were carried out on the intermediate CoO$\mathrm{Co} / \mathrm{CNF}$ sample in air atmosphere. TGA and DSC profiles of CoO-Co/CNF sample (Fig. 1a) show a first sharp peak at around $350^{\circ} \mathrm{C}$ that can be assigned to cobalt oxidation. A second peak in a temperature range $380-450{ }^{\circ} \mathrm{C}$ is due to the carbon nanofibers decomposition. Therefore, the 30 -minute procedure in air at $350{ }^{\circ} \mathrm{C}$ is considered the right compromise to obtain the oxidation of Co species avoiding the total burning of carbon nanofibers. Figure $1 \mathrm{~b}$ shows the thermogravimetric profile of the $\mathrm{Co}_{3} \mathrm{O}_{4} / \mathrm{CNF}$ in air. The percentage of oxide present is about 36 wt.\%. The higher content of $\mathrm{Co}_{3} \mathrm{O}_{4}$ compared to 
the $\mathrm{CoO}-\mathrm{Co} / \mathrm{CNF}$ sample (containing 20\%wt. of $\mathrm{CoO}-\mathrm{Co}$ ) is due to a partial decomposition of carbon nanofibers that occurs during the oxidation process at $350{ }^{\circ} \mathrm{C}$.
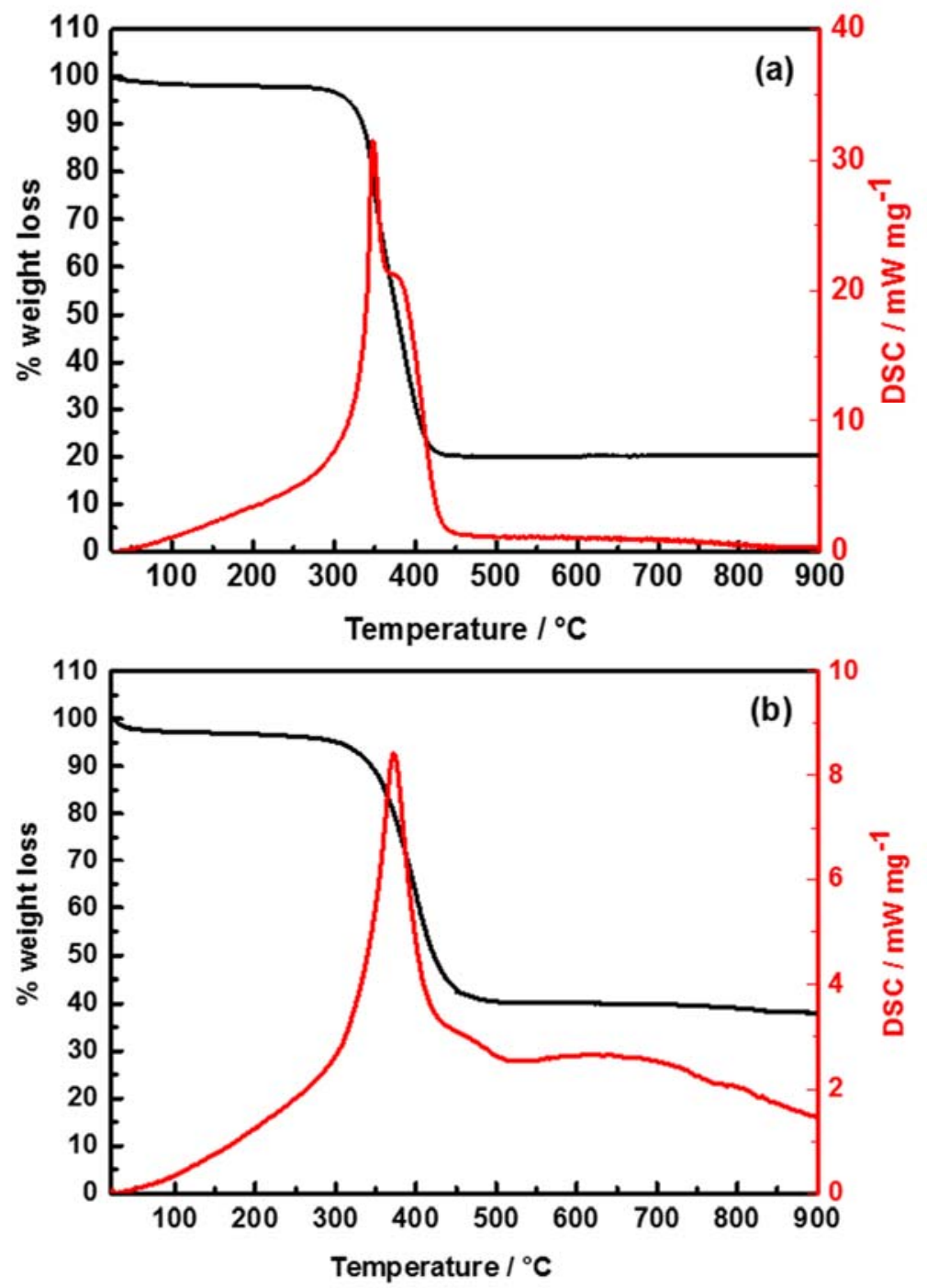

Figure 1. TGA and DSC profiles in air for: (a) $\mathrm{CoO}-\mathrm{Co} / \mathrm{CNF}$ [51]; (b) $\mathrm{Co}_{3} \mathrm{O}_{4} / \mathrm{CNF}$

The XRD spectrum, shown in Figure 2, presents the relative peaks of the cubic spinel structure. The peak appearing at 26 degrees is assigned to carbon of graphitic character, whose formation is favoured by the presence of cobalt (known as a graphitization catalyst [56]). Crystallite size, calculated by the Scherrer's formula, was around $10 \mathrm{~nm}$. 


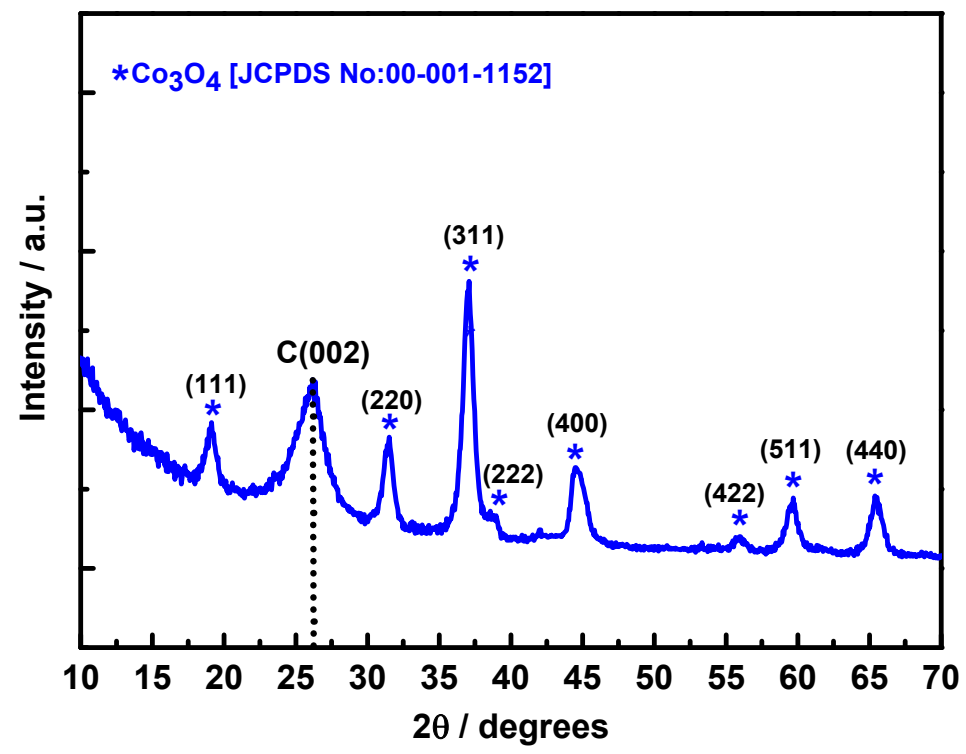

Figure 2. X-ray diffraction profiles for the spinel-type catalyst $\mathrm{Co}_{3} \mathrm{O}_{4} / \mathrm{CNF}$.

TEM image (Fig. 3a) shows the carbon nanofibers formation in which a good distribution of $\mathrm{Co}_{3} \mathrm{O}_{4}$ nanoparticles throughout these occurred. A CNFs size of about $200-300 \mathrm{~nm}$ is observed while an average $\mathrm{Co}_{3} \mathrm{O}_{4}$ particles size of about $11 \mathrm{~nm}$ is calculated, as also corroborated by XRD. The image at high magnification (Fig. 3b) shows the Co nanoparticles surrounded by the graphitic planes of carbon nanofibers characterized by a d-spacing value of about $0.34 \mathrm{~nm}$.
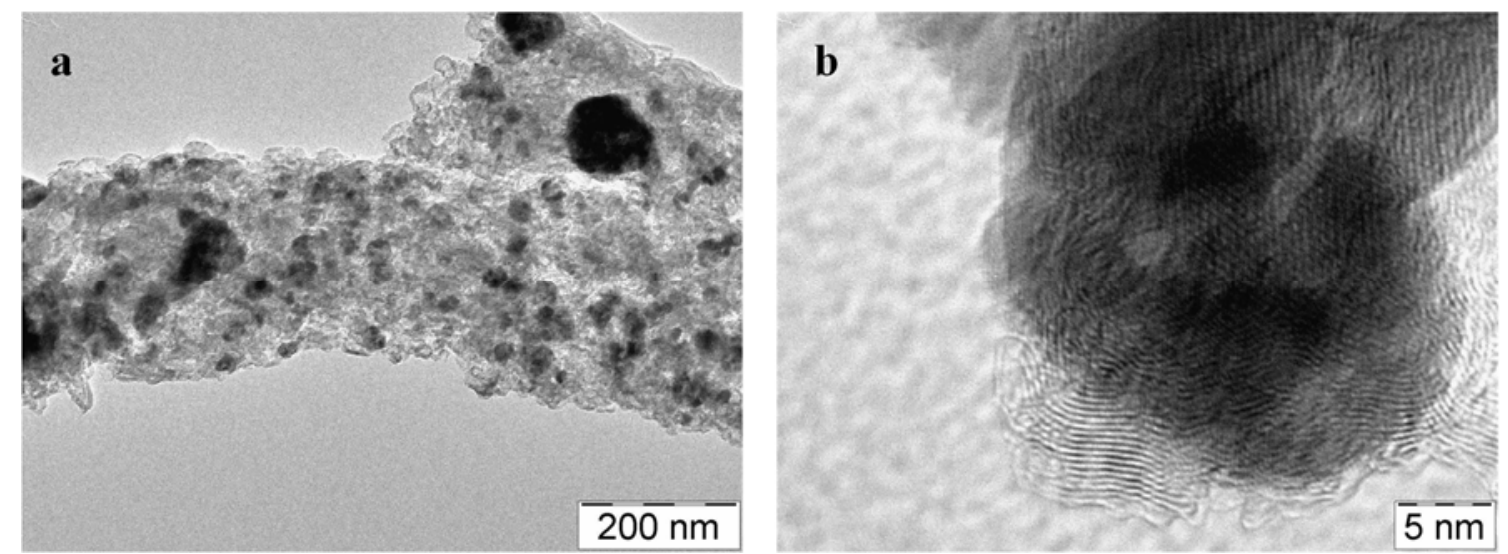

Figure 3. Images showing morphology of CNF, along with the crystallographic planes and dispersion over the surface of $\mathrm{Co}_{3} \mathrm{O}_{4}$ at a) low and b) high magnification. 
Figure 4 shows the adsorption-desorption isotherm (on the left) with the pore size distribution (on the right). The mixed spinel oxide and carbon nanofibers show type II isotherms, typical of macroporous solids and present a hysteresis loop attributable to the presence of mesopores (representing the $26 \%$ of the porosity). $\mathrm{Co}_{3} \mathrm{O}_{4} / \mathrm{CNF}$ presents a SBET equal to $187 \mathrm{~m}^{2} \mathrm{~g}^{-1}$.
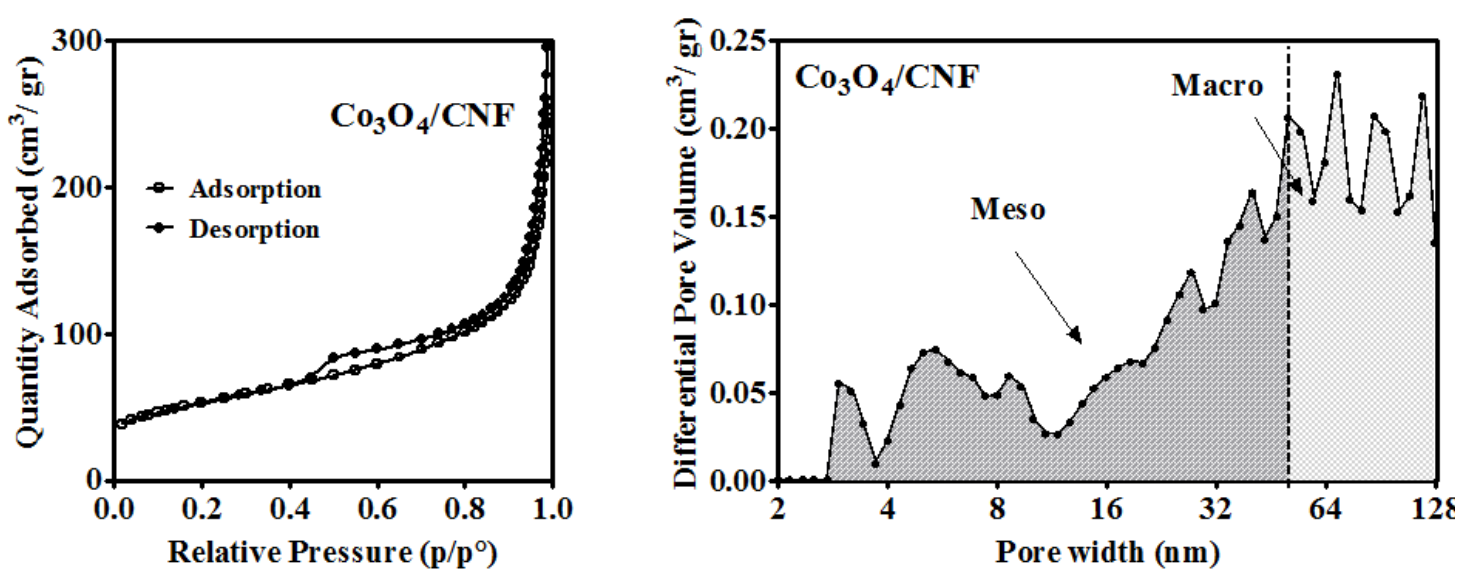

Figure 4. (Left) Profiles for the adsorption-desorption isotherms obtained from $\mathrm{N}_{2}$ physisorption and (right) representation of pore size distribution versus differential pore volume for the electrospun $\mathrm{Co}_{3} \mathrm{O}_{4} / \mathrm{CNF}$. (Areas in grey show mesopores and macropores percentage).

XPS analysis allowed determining the concentration (atomic \%) of the investigated elements (Table 1) as well as the oxidation state of the cobalt species. Deconvolution profiles are showed in Figures 5a to 5d. The Co2p spectrum (Fig. 5a) consists of two main peaks at binding energy values of $779.8 \mathrm{eV}\left(\mathrm{Co} 2 \mathrm{p}_{3 / 2}\right)$ and $795.2 \mathrm{eV}\left(\mathrm{Co} 2 \mathrm{p}_{1 / 2}\right)$ with a spin-orbit splitting energy of $15.4 \mathrm{eV}$ in agreement with the value reported in literature for $\mathrm{Co}_{3} \mathrm{O}_{4}$ spinel structure [57]. Moreover, two shake-up satellite peaks at around 787.4 $\mathrm{eV}$ and $803.6 \mathrm{eV}$ are observed. The shake-up satellites are located at a binding energy value of about $9 \mathrm{eV}$ higher than the main peaks indicating that the cobalt is present only 
in the spinel structure $\mathrm{Co}_{3} \mathrm{O}_{4}$ [58]. The deconvolution of $\mathrm{Co} 2 \mathrm{p}$ spectra also confirms the presence of the peaks due to the Co species in the $\mathrm{Co}^{2+}(779.63 \mathrm{eV}$ and $780.8 \mathrm{eV})$ and $\mathrm{Co}^{3+}(794.7 \mathrm{eV}$ and $796.2 \mathrm{eV})$ oxidation states. Another peak at $782 \mathrm{eV}$ is attributable to the presence of cobalt associated with nitrogen $\mathrm{Co}-\mathrm{N}_{\mathrm{x}}$.

Table 1. Atomic concentration of the elements obtained from XPS spectra.

\begin{tabular}{lcccc}
\hline Elements & C1s & N1s & O1s & Co2p \\
(at \%) & 83.8 & 2.8 & 9.5 & 3.8 \\
\hline
\end{tabular}
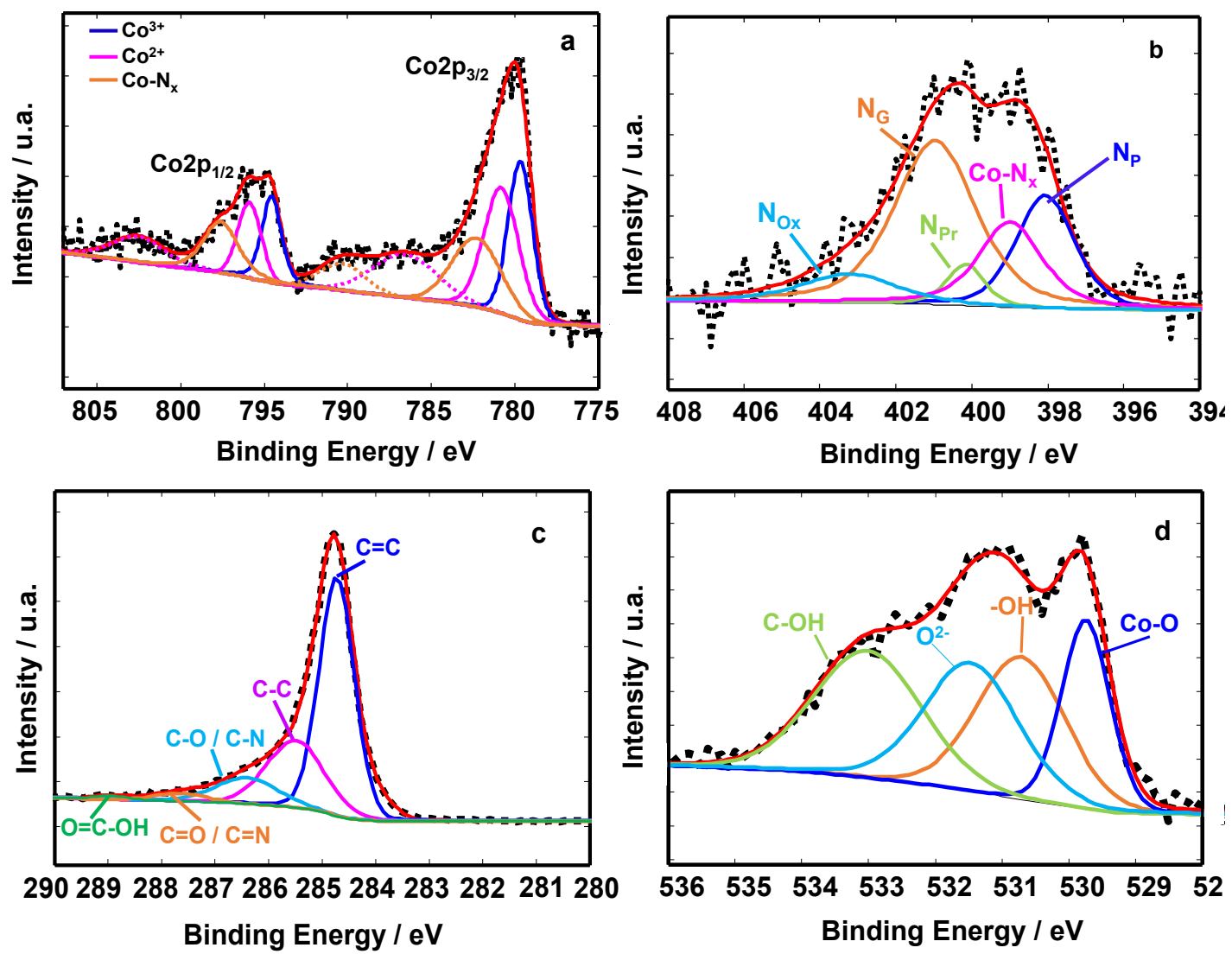

Figure 5. Deconvoluted XPS profiles for a) Co2p; b) N1s; c) C1s and d) O1s.

The amount (at \%) of all the cobalt species are reported in Table 2. A higher percentage of $\mathrm{Co}^{2+}$ with respect to $\mathrm{Co}^{3+}$ is calculated. 
Table 2. Co and N species (XPS atomic concentration).

\begin{tabular}{llllll}
\hline Type & Species & & & \\
\hline Co-Species & $\mathbf{C o}^{3^{+}}$ & $\mathbf{C o}^{2+}$ & $\mathbf{C o - N}$ & & \\
$\%$ & 27.8 & 43.6 & 28.6 & & \\
\hline N-Groups & $\mathbf{N}_{\mathbf{P}}$ & $\mathbf{C o - \mathbf { N } _ { \mathbf { x } }}$ & $\mathbf{N}_{\mathbf{P r}}$ & $\mathbf{N}_{\mathbf{G}}$ & $\mathbf{N}_{\mathbf{0 x}}$ \\
$\%$ & 23.0 & 21.0 & 5.3 & 41.0 & 9.7 \\
\hline
\end{tabular}

As reported in literature, the presence of an excess of cobalt (II) could cause a disorder lattice structure leading to the creation of a larger number of oxygen vacancies [59]. The oxygen vacancies on the surface of $\mathrm{Co}_{3} \mathrm{O}_{4}$ improve the electrical conductivity and increase the availability of active sites enhancing the electrocatalytic activity for OER [60,61]. The deconvolution of N1s spectra (Fig. 5b) shows the presence of different peaks associated with nitrogen species whose amounts are reported in Table 2. Pyridinic $\mathrm{N}$ (denoted as $\mathrm{N}_{\mathrm{P}}$ ) was assigned to peaks at $398 \mathrm{eV}$. Graphitic $\mathrm{N}$ (denoted as $\mathrm{N}_{\mathrm{G}}$ ) was ascribed to peaks appearing at $401 \mathrm{eV}$. Both species derived from the PAN precursors [51,62]. Co-Nx species appeared at $399 \mathrm{eV}$. A small contribution from pyrrolic $\mathrm{N}$ (denoted as $\mathrm{N}_{\mathrm{Pr}}$ ) appearing at $400 \mathrm{eV}$ and oxidized $\mathrm{N}$ (denoted as $\mathrm{N}_{\mathrm{ox}}$ ) at $403 \mathrm{eV}$ were also found, respectively (Table 2). The C1s spectrum (Fig. 5c) was divided in four contributions corresponding to graphitic carbon $(284.8 \mathrm{eV})$ and amorphous carbon (285.5 eV), as the main contributors, and in a lower intensity, C-O/C-N (286.5 eV) and $\mathrm{C}=\mathrm{O} / \mathrm{C}=\mathrm{N}(287.6 \mathrm{eV})$, indicative of the presence of hydoxyl and carbonyl species as well as nitrile species, respectively. Moreover, a further peak is identified at $289 \mathrm{eV}$ attributable to carboxylic species $(\mathrm{O}=\mathrm{C}-\mathrm{O})$ [63]. The peaks deconvolution analysis of O1s spectrum (Fig.5d) reveals the presence of metal oxygen bonds (Co-O) with a peak centered at $529.8 \mathrm{eV}$. The peak at $530.7 \mathrm{eV}$ can be ascribed to the oxygen in OH-group form. The peak at $531.5 \mathrm{eV}$ is due to the $\mathrm{O}_{2}-$ ions at low coordination number in the 
oxide sample [64]. C-OH phenolic groups were also found on the surface of carbon nanofibers surface as confirmed by the peak at $533.4 \mathrm{eV}[65]$.

\subsection{Electrocatalytic activity evaluation}

The activity of the spinel electro-catalyst towards the oxygen evolution and the oxygen reduction reactions was evaluated in an alkaline solution by means of rotating disk electrode (RDE) measurements. Fig. 6 shows the profiles for the assessment of the activity towards the reduction reaction for the $\mathrm{Co}_{3} \mathrm{O}_{4} / \mathrm{CNF}$. LSVs were recorded at 1600 rpm rotation speed in a $1 \mathrm{M} \mathrm{KOH}$ basic solution saturated with oxygen, in comparison to a previously reported catalyst, $\mathrm{CoO}-\mathrm{Co} / \mathrm{CNF}$, and to SoA benchmark catalysts: for the ORR, $\mathrm{Pt} / \mathrm{C}$ and, for the $\mathrm{OER}, \mathrm{IrO}_{2}[51]$.

\subsubsection{Oxygen reduction reaction}

Both cobalt-based materials present almost the same onset potential, $0.92 \mathrm{~V}$ vs. RHE, as $\mathrm{Pt} / \mathrm{C}$ (only $3 \mathrm{mV}$ more positive). This is a remarkable result for a non-precious metal catalyst. Besides, the spinel $\mathrm{Co}_{3} \mathrm{O}_{4} / \mathrm{CNF}$ reaches a limiting current density comparable to that of $\mathrm{Pt} / \mathrm{C}$, and significantly superior to its counterpart $\mathrm{CoO}-\mathrm{Co} / \mathrm{CNF}$. This may be due to the differences in the oxidation state of cobalt in $\mathrm{Co}_{3} \mathrm{O}_{4} / \mathrm{CNF}$ and $\mathrm{CoO}-\mathrm{Co} / \mathrm{CNF}$. $\mathrm{Co}_{3} \mathrm{O}_{4} / \mathrm{CNF}$ presents a mixture of $\mathrm{Co}^{2+}$ and $\mathrm{Co}^{3+}\left(28\right.$ at. $\%$ of $\mathrm{Co}^{3+}$ and 44 at. $\%$ of $\left.\mathrm{Co}^{2+}\right)$. 


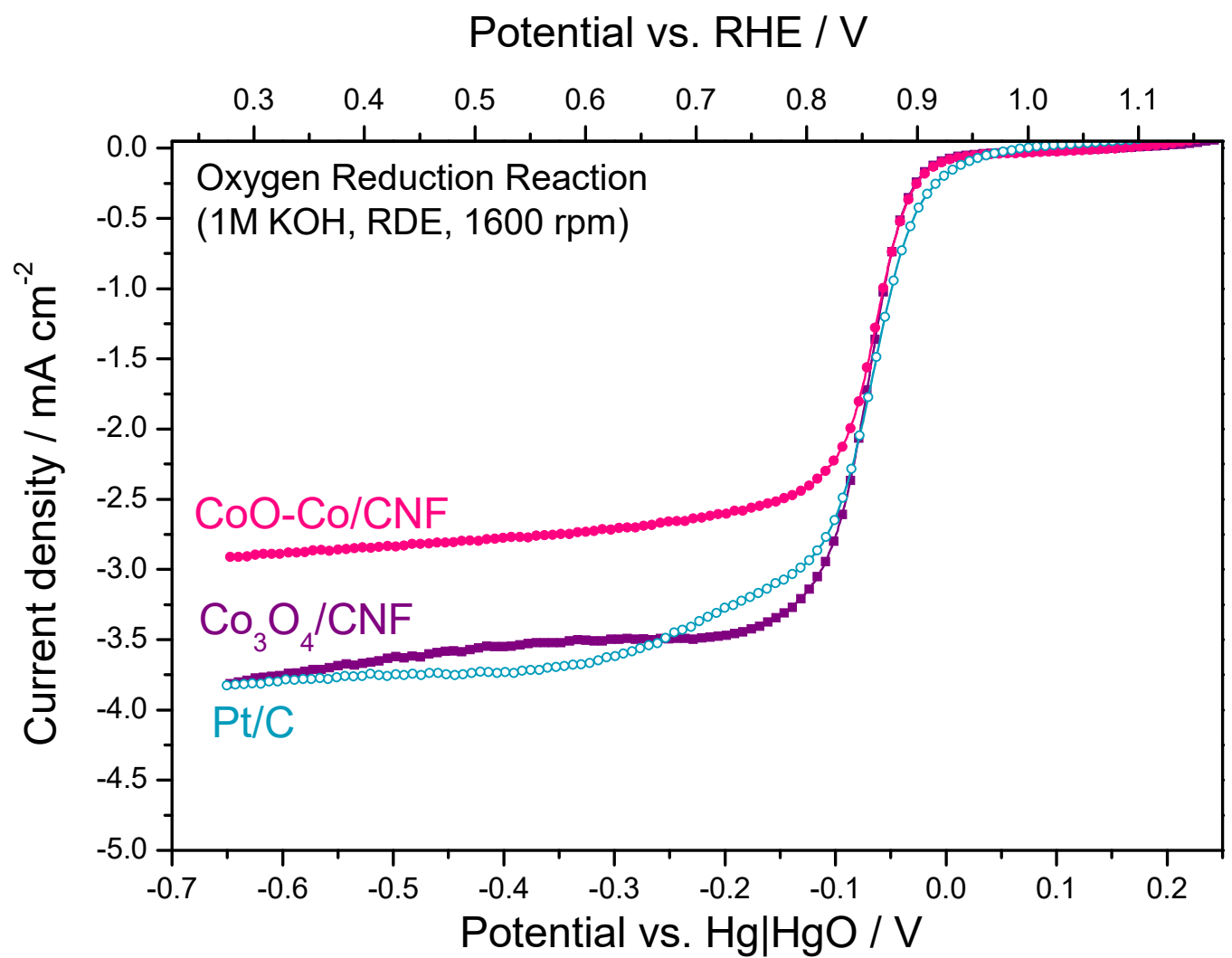

Fig. 6. Linear Sweep Voltrametries recorded (a) during oxygen reduction reaction for the spinel-type electro-catalyst (rotation speed $=1600 \mathrm{rpm}$ ). Benchmark catalysts $(\mathrm{Pt} / \mathrm{C}$ and $\mathrm{CoO}-\mathrm{Co} / \mathrm{CNF}$ ) are also tested for the sake of comparison as state-of-the-art catalyst.

It has been proved that $\mathrm{Co}^{2+}$ species favour the ORR due to the favoured adsorption of $\mathrm{O}_{2}$. This entails the creation of $\mathrm{OH}^{-}$(due to the subsequent electron transfer) that carry on the reaction [4].With this in consideration, $\mathrm{CoO}-\mathrm{Co} / \mathrm{CNF}$ should present a higher ORR activity, due to the higher amount of $\mathrm{Co}^{2+}$ (75 at. \% vs $44 \%$ for $\mathrm{Co}_{3} \mathrm{O}_{4} / \mathrm{CNF}$ ). However, $\mathrm{N}$-sites also play a major role in oxygen electrocatalysis. Recently, it has been reported that the quaternary $\mathrm{N}$ atoms in $\mathrm{N}$-doped carbon materials enhance $\mathrm{O}_{2}$ adsorption and accelerated the ORR by providing electrons to the p-conjugated system $[33,66]$. The percentage of N-species, as determined by XPS, in both Co-based samples differs considerably. The most notable difference is the amount of graphitic N, being almost double for the $\mathrm{Co}_{3} \mathrm{O}_{4} / \mathrm{CNF}$ material (41 at. \% vs. 28 at. \% for $\mathrm{CoO}-\mathrm{Co} / \mathrm{CNF}$ ), what would explain the higher ORR activity for the spinel-type material. Besides, both cobalt-based 
samples present cobalt atoms bonded to $\mathrm{N}$ in the form of $\mathrm{Co}-\mathrm{Nx}$, showing $\mathrm{Co}_{3} \mathrm{O}_{4} / \mathrm{CNF}$ a higher percentage of this ORR-active species ( 29 at \% vs. 21 at \% for CoO-Co/CNF). Co$\mathrm{N}_{\mathrm{x}}$ sites are also recognized as contributors to the initial adsorption of oxygen, which is subsequently converted to the intermediate reaction products. The higher amount of Co$\mathrm{N}_{\mathrm{x}}$ species in the spinel-type material also contributes to its higher catalytic activity (in comparison to $\mathrm{CoO}-\mathrm{Co} / \mathrm{CNF}$ ) [51]. In summary, a combination of different $\mathrm{O}$-active species (graphitic $\mathrm{N}$, i.e. quaternary $N$ bonds, Co- $\mathrm{N}_{\mathrm{x}}$ and $\mathrm{Co}^{2+}$ ) are responsible for the enhanced catalytic activity of the spinel-type electrocatalyst assessed in this work. Figure 7a shows the LSV curves at different rotation speed for $\mathrm{Co}_{3} \mathrm{O}_{4} / \mathrm{CNF}$ along with the Koutecky-Levich plots (Figure $7 \mathrm{~b}$ ) that provide the number of electrons exchanged during the oxygen reduction reaction. K-L plots determined a $4 \mathrm{e}^{-}$mechanism $\left(4.07 \mathrm{e}^{-}\right)$. This indicates that our catalyst performs the ORR through the preferred and more efficient $4 \mathrm{e}^{-}$-mechanism, reducing $\mathrm{O}_{2}$ to $\mathrm{H}_{2} \mathrm{O}$. The $\mathrm{CoOCo} / \mathrm{CNF}$ catalyst presented also a $4 \mathrm{e}^{-}$ mechanism (with a value of $3.8 \mathrm{e}^{-}$determined from the Koutecky-Levich plots, as described in detail in ref. [51]). 
(a)

Potential versus RHE / V

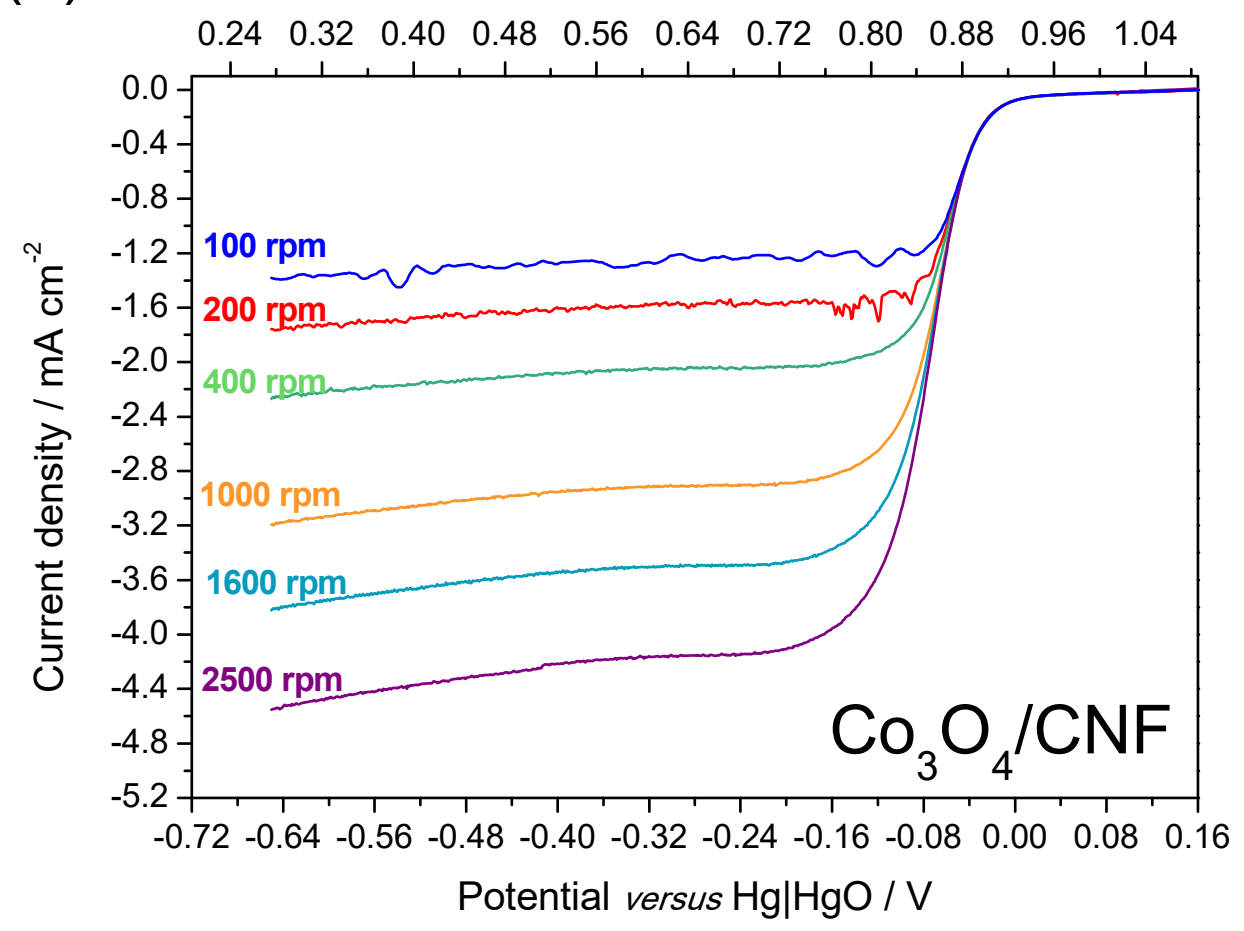

(b)

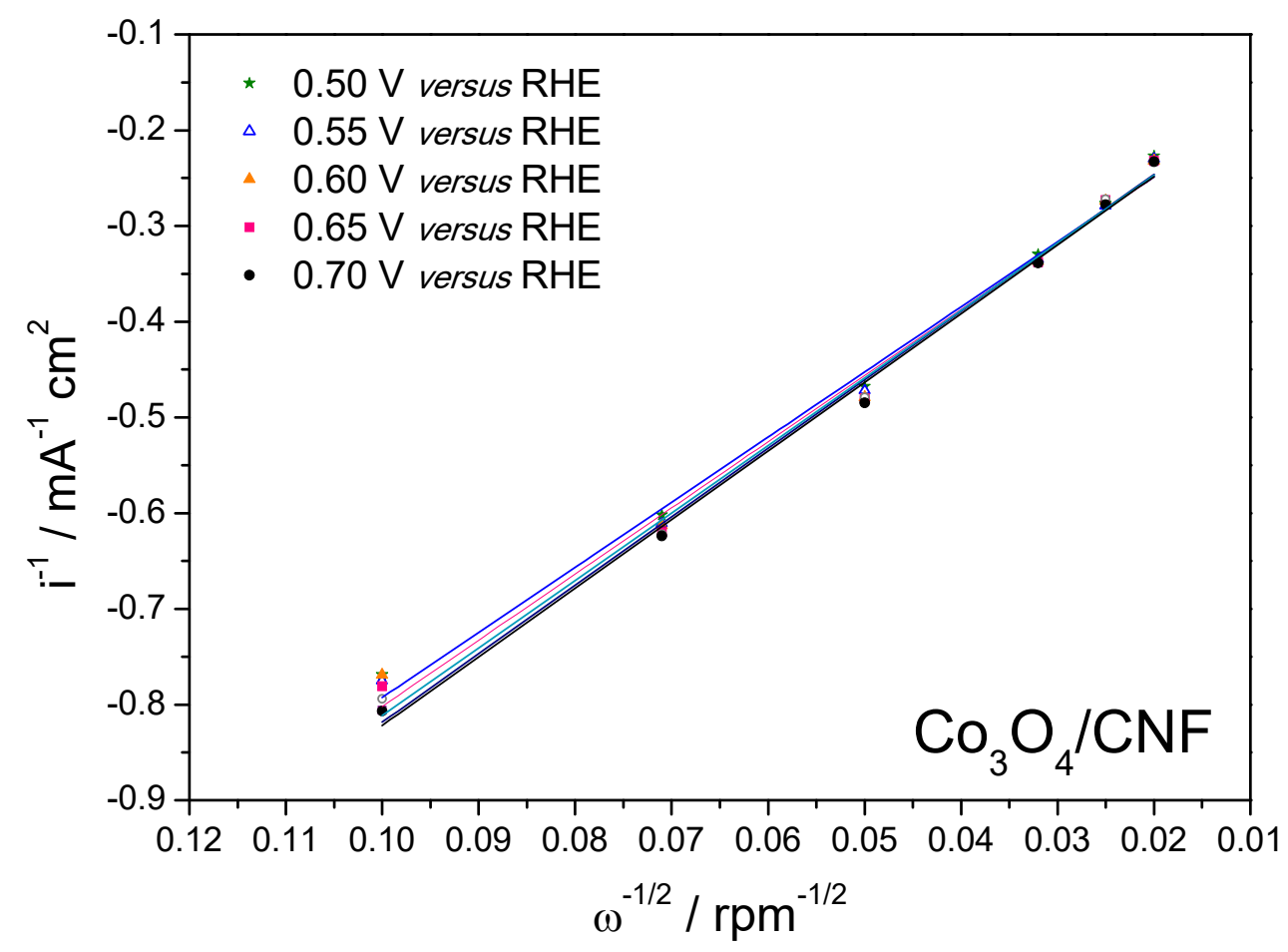

Figure 7. (a) Profiles for LSV curves obtained at 100, 200, 400, 1000, 1600 and 2500 $\mathrm{rpm}$ in a solution of $\mathrm{KOH}(1 \mathrm{M})$ saturated with $\mathrm{O}_{2}$ (scan rate $\left.=5 \mathrm{mV} \mathrm{s}^{-1}\right)$. (b) Representation of the Koutecky-Levich plots at different voltages to determine kinetic parameters. 


\subsubsection{Oxygen evolution reaction}

The oxygen evolution reaction performance, shown in Figure 8, shows that the $\mathrm{Co}_{3} \mathrm{O}_{4} / \mathrm{CNF}$ catalyst presents the best performance, $120 \mathrm{~mA} \mathrm{~cm}^{-2}$ at $1.8 \mathrm{~V}$ vs RHE, outperforming both the $\mathrm{IrO}_{2}$-benchmark catalyst and the $\mathrm{CoO}-\mathrm{Co} / \mathrm{CNF}$ catalyst. The mechanism for catalytic active sites is still unknown, but it has been proved that catalysts with higher amounts of $\mathrm{Co}^{3+}$ species present higher OER activities. This could be due to a preferred absorption of $\mathrm{OH}^{-}$anions on $\mathrm{Co}^{3+}$ species, acting as active species for the OER [4]. On the other hand, also N-sites have been reported as active for the OER. Recently, Yang et al. determined that $\mathrm{N}$ in the form of pyridinic species accepts electrons from adjacent $\mathrm{C}$ atoms. This facilitates the adsorption of $\mathrm{OH}^{-}$and $\mathrm{OOH}^{-}$(water oxidation intermediates), being the rds (rate-determining step) for OER in basic media. The difference in pyridinic- $\mathrm{N}$ between $\mathrm{CoO}-\mathrm{Co} / \mathrm{CNF}$ and $\mathrm{Co}_{3} \mathrm{O}_{4} / \mathrm{CNF}$ is small, but there is a significant difference in the amount of $\mathrm{Co}^{3+}$ between the two examined samples. CoO$\mathrm{Co} / \mathrm{CNF}$ does not present cobalt in the oxidation state III, $\mathrm{Co}^{3+}$, so the main explanation for the large activity of $\mathrm{Co}_{3} \mathrm{O}_{4}$ for the OER versus $\mathrm{CoO}-\mathrm{Co} / \mathrm{CNF}$ might reside on that. 


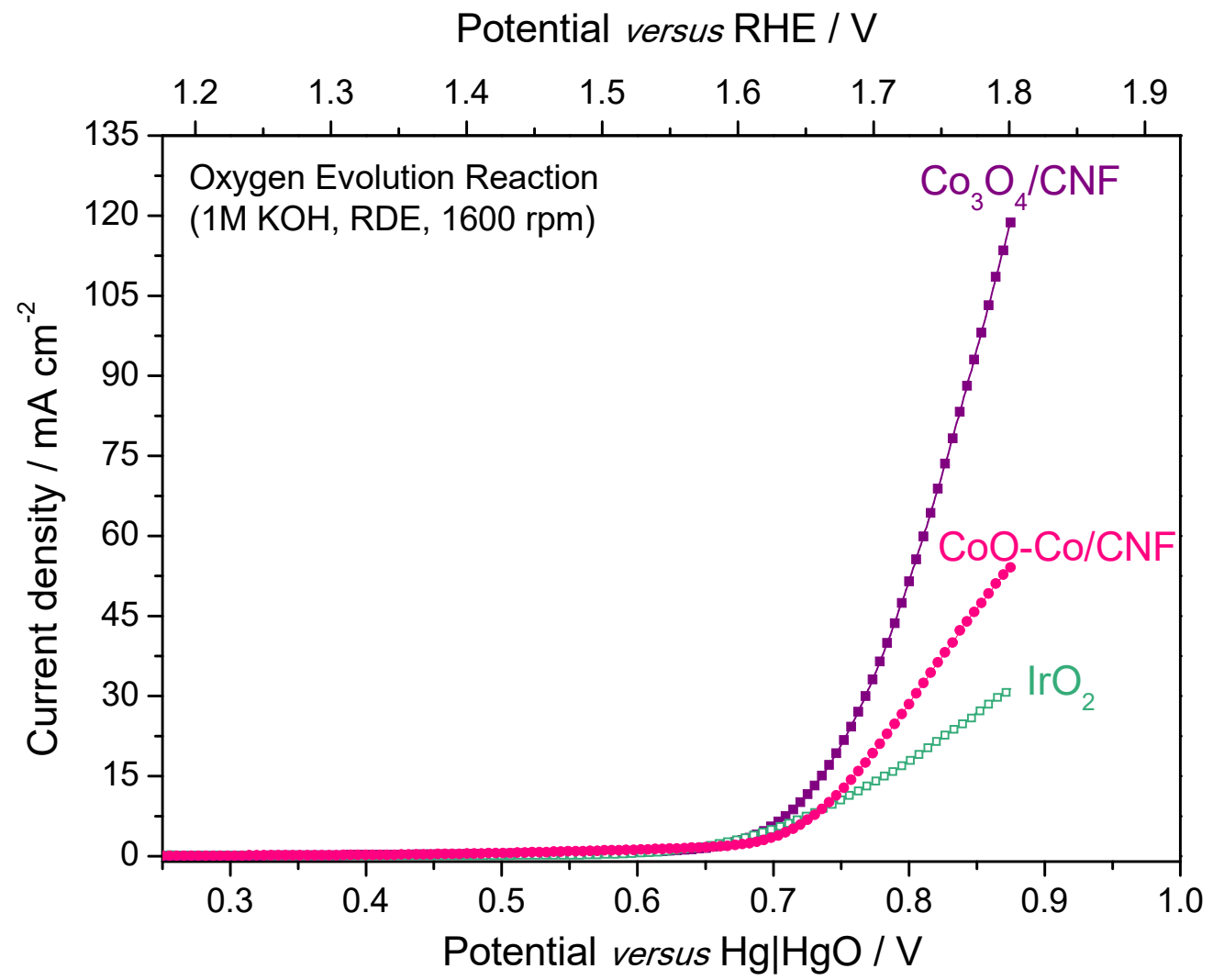

Fig. 8. Linear Sweep Voltametries recorded during the oxygen evolution reaction (rotation speed $=1600 \mathrm{rpm}, \mathrm{He}$ atmosphere) for the spinel-type electro-catalyst, in comparison with $\mathrm{CoO}-\mathrm{Co} / \mathrm{CNF}$ and $\mathrm{IrO}_{2}$ as benchmark catalysts.

At these high potentials, carbon materials may be oxidized to $\mathrm{CO}_{2}$. Other authors have studied the behaviour in different media of several nanostructured carbonaceous materials, like carbon blacks and CNFs $[48,67,68]$ showing that the stability of carbon at high potentials is a critical aspect. In a previous work, we carried out a comparison between the carbon material (electrospun $\mathrm{CNF}$ ) and the Co-based CNF (CoO-Co/CNF), so as to determine the effect of the CNF on the electro-activity for the evolution of oxygen. In that case, the activity for the OER of the $\mathrm{CoO}-\mathrm{Co} / \mathrm{CNF}$ electro-catalyst was so high that, the contribution to the current density due to the oxidation of carbon, was considered negligible [51]. 
The choice of using cobalt oxides as bifunctional catalysts has attracted a great deal of research $[8,27-33]$. The bifunctional behaviour of the air electrodes is vital for the correct performance of the battery. A way to evaluate the reversibility (i.e. the bifunctionality) of the system is the use of the parameter $\Delta \mathrm{E}$, i.e, the value corresponding to the difference between potentials at a certain current density on both reactions. For the OER, the value of the potential at $10 \mathrm{mAcm}^{-2}$ is considered, whereas for the ORR, the half-wave potential is used. $\Delta \mathrm{E}$ along with other parameters such as onset potential, overpotential for the OER ( $\eta$ ) are shown in Table 3, in comparison to the most recent works in the literature. The voltage at $10 \mathrm{~mA} \mathrm{~cm}^{-2}$ (denoted as $\mathrm{Ej}=10$ ) is generally used to evaluate OER activity $[27,69]$. The spinel type material, $\mathrm{Co}_{3} \mathrm{O}_{4} / \mathrm{CNF}$ possesses an $\Delta \mathrm{E}$ value equal to $795 \mathrm{mV}$, within the best two-three values reported in literature (up to our knowledge). On the other hand, our over-potential for the OER is slightly higher $(416 \mathrm{mV})$ in comparison to lower values (such as $280,340 \mathrm{mV}$ ) [27,31,40,69,70]. However, the catalysts employed are obtained with more complex carbon structures such as graphene, particular exposed faces of the $\mathrm{Co}_{3} \mathrm{O}_{4}$ structure, etc., not so easily scalable as our $\mathrm{Co}_{3} \mathrm{O}_{4}$ spinel on electrospun carbon nanofibers. 
Table 3. Electrochemical parameters obtained from the RDE measurements (Eonset, Ehwp, and $I_{d}$ stand for onset potential, half-wave potential, and

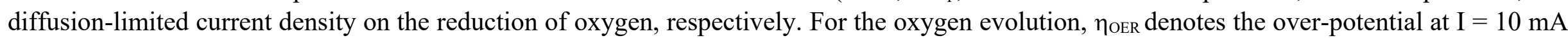
$\mathrm{cm}^{-2}, \mathrm{I}_{\mathrm{S}}$ stands for the current density at $1.70 \mathrm{~V}$ vs. RHE and $\Delta \mathrm{E} / \mathrm{mV}\left(\mathrm{E}_{\mathrm{ORR}}-\mathrm{E}_{\mathrm{OER}}\right)$ is the voltage difference between the $\mathrm{E}_{\mathrm{hwp}}$ and $\mathrm{E}_{\mathrm{OER}}\left(\mathrm{at} 10 \mathrm{~mA} \mathrm{~cm}^{-2}\right)$. 


\begin{tabular}{|c|c|c|c|c|c|c|c|c|c|}
\hline \multirow[b]{2}{*}{ Catalyst } & \multicolumn{3}{|c|}{ ORR } & \multicolumn{3}{|c|}{ OER } & \multirow{2}{*}{$\begin{array}{c}\text { Reversibility } \\
\\
\Delta E / m V \\
\left(E_{\text {ORR }}-\mathbf{E}_{\text {OER }}\right)\end{array}$} & \multirow{2}{*}{$\begin{array}{r}{[\mathrm{KOH}]} \\
\mathrm{mol} / \mathrm{L}\end{array}$} & \multirow[b]{2}{*}{ Ref } \\
\hline & $\mathbf{E}_{\text {onset }}$ & $\mathbf{E}_{\mathrm{hwp}} / \mathbf{m V}$ & Id & $\begin{array}{c}\text { EOER }_{\text {OER }} \\
\mathbf{m V} @ \\
10 \\
\mathbf{m A c m} \\
-2\end{array}$ & $\begin{array}{c}\text { クOER@ } \\
10 \\
\text { mAcm }^{-2} / \\
\mathbf{m V}\end{array}$ & $\begin{array}{c}\text { Is }_{\text {s }} 1.7 \mathrm{~V} \\
\text { (vs RHE) / } \\
\mathrm{mA} \mathrm{cm} \text { cm }^{-2}\end{array}$ & & & \\
\hline $\mathrm{Co}_{3} \mathrm{O}_{4} / \mathrm{CNF}$ & 919 & 851 & -3.8 & 1646 & 416 & 34 & 795 & & This work \\
\hline $\mathrm{CoO}-\mathrm{Co} / \mathrm{CNF}$ & 922 & 858 & -2.9 & 1667 & 437 & 19 & 809 & & \\
\hline Pd/Vulcan & 912 & 846 & -3.6 & 1698 & 479 & 9 & 852 & $1 \mathrm{M}$ & \\
\hline Pt/Vulcan & 944 & 855 & -3.8 & 1741 & 510 & 6 & 886 & & \\
\hline $\mathrm{IrO}_{2}$ & 827 & 589 & -2.0 & 1671 & 442 & 14 & 1082 & & \\
\hline $\mathrm{Co}_{3} \mathrm{O}_{4}-\mathrm{NP} / \mathrm{N}-\mathrm{rGO}$ & 890 & 760 & -5.5 & 1610 & 380 & 85 & 850 & $0.1 \mathrm{M}$ & {$[33]$} \\
\hline $\mathrm{Co}_{3} \mathrm{O}_{4}-\mathrm{NF}(\mathrm{C})$ & $\approx 650$ & 610 & $\approx-4.8$ & $\approx 1650$ & $\approx 420$ & $\approx 80$ & $\approx 1040$ & $1 \mathrm{M}$ & {$[27]$} \\
\hline $\mathrm{Co}_{3} \mathrm{O}_{4} / \mathrm{N}-\mathrm{GAs} *$ & 970 & 870 & -5.2 & 1660 & 430 & $\approx 15$ & 790 & $1 \mathrm{M}$ & [69] \\
\hline Co-N@HCS & 962 & 864 & -5.5 & 1720 & 490 & $\approx 8$ & 856 & $0.1 \mathrm{M}$ & {$[40]$} \\
\hline $\mathrm{Co} @ \mathrm{Co}_{3} \mathrm{O}_{4} / \mathrm{N}-\mathrm{CNT}$ & - & 800 & $\approx-4.5$ & 1650 & 420 & $\approx 25$ & 850 & $0.1 \mathrm{M}$ & {$[31]$} \\
\hline Co-oxide/3D-G & 900 & 810 & -1.9 & 1570 & 340 & $\approx 25$ & 760 & $1 \mathrm{M}$ & {$[70]$} \\
\hline
\end{tabular}


The activity of the spinel material was also evaluated in a gas diffusion electrode to test our catalyst in more realistic conditions. Polarizations were performed in the same potential window employed during the RDE studies. Besides, durability of the catalyst was evaluated with a long test (21-hour chronopotentiometry) at a current density of -80 $\mathrm{mA} / \mathrm{cm}^{2}$. The activity of the $\mathrm{Co}_{3} \mathrm{O}_{4} / \mathrm{CNF}$ was also evaluated before and at the end of the test, as shown in Figure 9a. During the chronopotentiometry test (Figure 9b), the potential shows a stable behaviour (being kept between 0.72 and $0.68 \mathrm{~V}$ vs RHE). Before the end of the test (after ca. $18 \mathrm{~h}$ of experiment), there was an interruption of the current; successively, the potential rose around $40 \mathrm{mV}$. The activity of the $\mathrm{Co}_{3} \mathrm{O}_{4} / \mathrm{CNF}$ (Figure 9a) in terms of potential slightly improves after the chronotest, showing the remarkable stability of our catalyst.

(a)

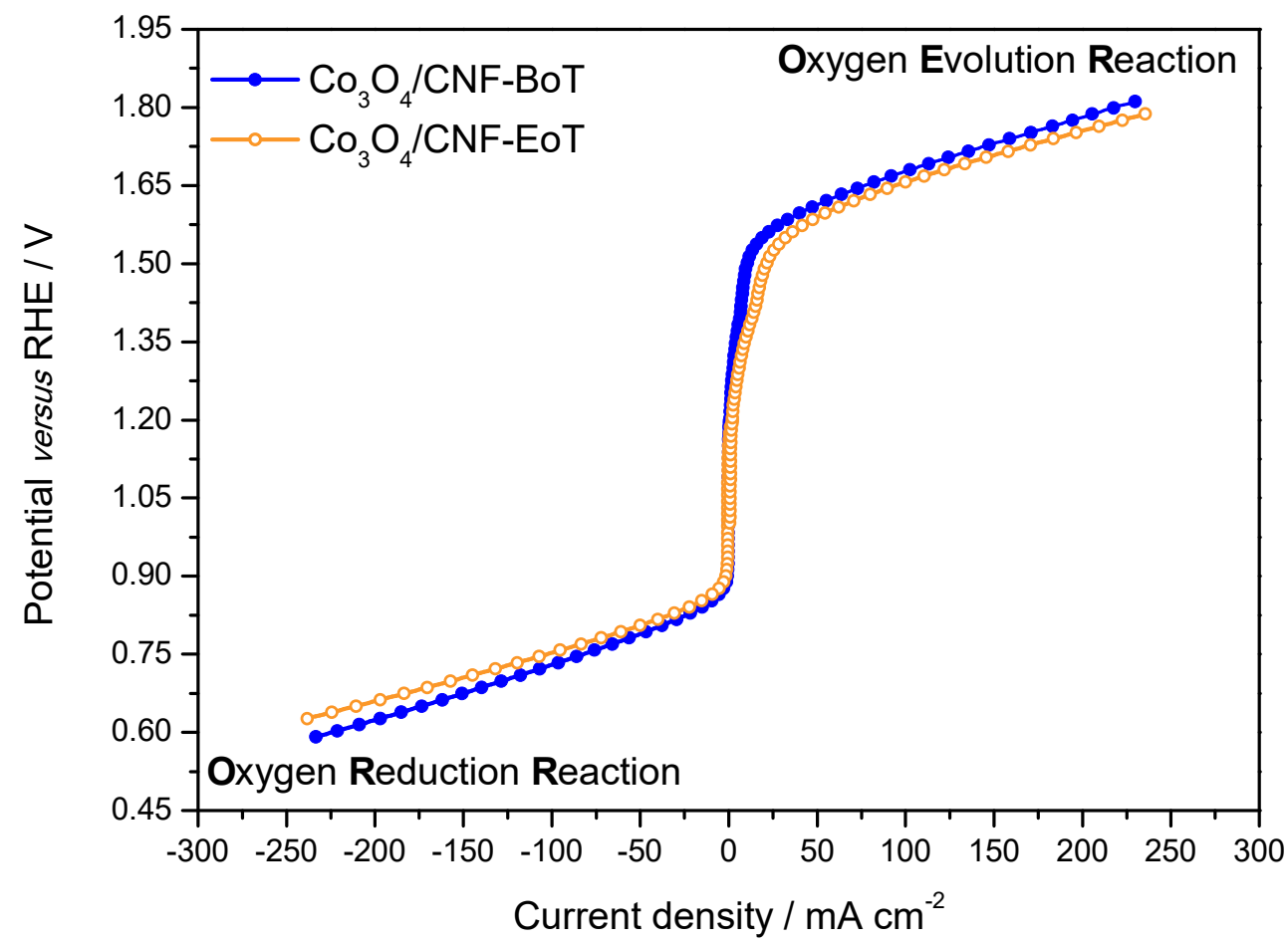


(b)

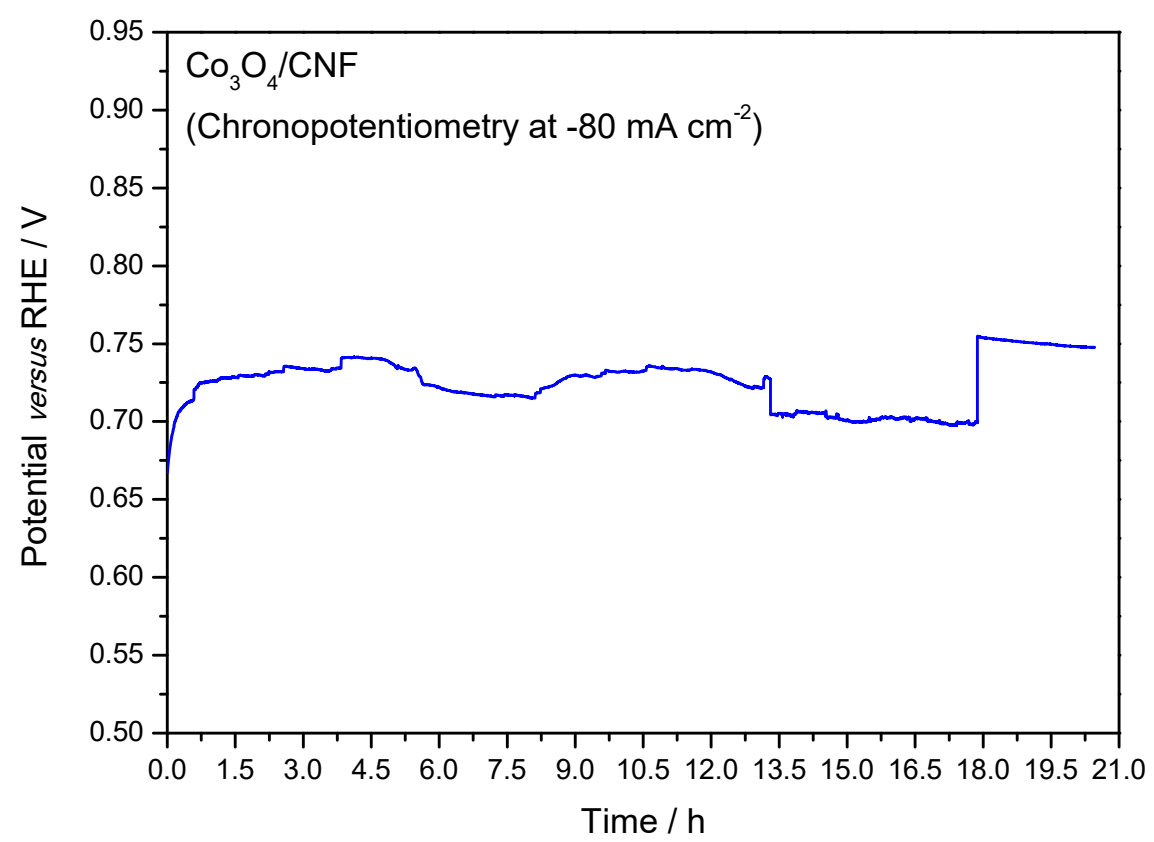

Fig.9. (a) Profile for the polarization curves during oxygen reduction and oxygen evolution reactions, recorded in a gas diffusion-type working electrode in a $6 \mathrm{M} \mathrm{KOH}$ electrolyte for the spinel-type material, $\mathrm{Co}_{3} \mathrm{O}_{4} / \mathrm{CNF}$, at the beginning (BoT) and at the end (EoT) of the chonopotentiometric test. The employed scan rate was equal to $5 \mathrm{mV}$ $\mathrm{s}^{-1}$. (b) Potential profile during the chronopotentiometric test $(21 \mathrm{~h})$ at reduction currents (negative) of $80 \mathrm{~mA} / \mathrm{cm}^{2}$ flowing $\mathrm{O}_{2}$ in the electrolyte.

\section{Conclusions}

A spinel type $\mathrm{Co}_{3} \mathrm{O}_{4}$ oxide was synthesized by electrospinning of a conductive polymer. Electrospun carbon nanofibers with well distributed $\mathrm{Co}_{3} \mathrm{O}_{4}$ spinel-type particles were obtained by a simple, scalable and reproducible method. $\mathrm{Co}_{3} \mathrm{O}_{4} / \mathrm{CNF}$ presented a remarkable electro-catalytic activity as bifunctional catalyst, being able to catalyze the oxygen reduction and the oxygen evolution reactions. This work proved the suitability of the spinel cobalt oxide to be used in the positive electrode (acting as air electrode) in a metal-air battery, or other devices needing bifunctionality.

The combination of both conductivity and porous structure of the carbon material, along with the presence of oxygen-active species were responsible for the remarkable catalytic performance of this material for the electro-catalysis of oxygen. In particular, the presence 
of both $\mathrm{Co}^{2+}$, graphitic-N and $\mathrm{Co}-\mathrm{Nx}$ enhanced the oxygen reduction reaction, whereas abundance of $\mathrm{Co}^{3+}$ and pyridinic $\mathrm{N}$ were responsible for the excellent performance towards the oxygen evolution reaction. The spinel type material showed electrochemical features of interest such as low evolution overpotential, superior or comparable onset and half-wave potentials to the ones for the SoA catalyst, $\mathrm{Pt} / \mathrm{C}$ as well as a remarkable reversibility. The activity of the spinel material was also evaluated in a gas diffusion electrode to test our catalyst in more realistic conditions. During the chronopotentiometry test, the potential shows a stable behavior. Besides, the activity of the $\mathrm{Co}_{3} \mathrm{O}_{4} / \mathrm{CNF}$ in terms of potential slightly improved after the chronotest, showing the remarkable stability of our catalyst. For these reasons, spinel- $\mathrm{Co}_{3} \mathrm{O}_{4}$ on electrospun nanofibers are expected to be a convenient and promising material acting as air electrodes on metal-air batteries.

\section{Acknowledgements}

Funding for this work was obtained from the "Accordo di Programma CNR-MiSE, Gruppo tematico Sistema Elettrico Nazionale - Progetto: Sistemi elettrochimici per l'accumulo di energia". 


\section{References}

[1] Q. Wei, Y. Fu, G. Zhang, S. Sun, Rational design of carbon-based oxygen electrocatalysts for zinc-air batteries, Curr. Opin. Electrochem. 4 (2017) 45-59. doi:10.1016/J.COELEC.2017.09.006.

[2] M.P. Browne, Z. Sofer, M. Pumera, Layered and two dimensional metal oxides for electrochemical energy conversion, Energy Environ. Sci. (2019). doi:10.1039/C8EE02495B.

[3] X. Cai, L. Lai, J. Lin, Z. Shen, Recent advances in air electrodes for Zn-air batteries: electrocatalysis and structural design, Mater. Horiz. 4 (2017) 945-976. doi:10.1039/C7MH00358G.

[4] H. Osgood, S. V. Devaguptapu, H. Xu, J. Cho, G. Wu, Transition metal (Fe, Co, Ni, and $\mathrm{Mn}$ ) oxides for oxygen reduction and evolution bifunctional catalysts in alkaline media, Nano Today. 11 (2016) 601-625. doi:10.1016/J.NANTOD.2016.09.001.

[5] R. Cao, J.-S.S. Lee, M. Liu, J. Cho, Recent progress in non-precious catalysts for metalair batteries, Adv. Energy Mater. 2 (2012) 816-829. doi:10.1002/aenm.201200013.

[6] X. Zhang, K. Tsay, W. Qu, J. Fahlman, Bi-functional air electrode fabrication, performance and stability evaluation, J. Energy Storage. 20 (2018) 520-528. doi:10.1016/J.EST.2018.10.002.

[7] M. Chen, L. Wang, H. Yang, S. Zhao, H. Xu, G. Wu, Nanocarbon/oxide composite catalysts for bifunctional oxygen reduction and evolution in reversible alkaline fuel cells: A mini review, J. Power Sources. 375 (2018) 277-290. doi:10.1016/J.JPOWSOUR.2017.08.062.

[8] S. Zhou, N. Liu, Z. Wang, J. Zhao, Nitrogen-Doped Graphene on Transition Metal Substrates as Efficient Bifunctional Catalysts for Oxygen Reduction and Oxygen Evolution Reactions, ACS Appl. Mater. Interfaces. 9 (2017) 22578-22587. doi:10.1021/acsami.7b05755.

[9] G. Wu, A. Santandreu, W. Kellogg, S. Gupta, O. Ogoke, H. Zhang, H.-L.L. Wang, L. Dai, Carbon nanocomposite catalysts for oxygen reduction and evolution reactions: From nitrogen doping to transition-metal addition, Elsevier, 2016. doi:10.1016/j.nanoen.2015.12.032.

[10] J.M. Luque-Centeno, M.V. Martínez-Huerta, D. Sebastián, G. Lemes, E. Pastor, M.J. Lázaro, Bifunctional N-doped graphene Ti and Co nanocomposites for the oxygen reduction and evolution reactions, Renew. Energy. 125 (2018) 182-192. doi:10.1016/J.RENENE.2018.02.073.

[11] U. Sahapatsombut, H. Cheng, K. Scott, Modelling of a Na-air battery with porous gas diffusion electrode, J. Energy Storage. 7 (2016) 220-235. doi:10.1016/J.EST.2016.07.001.

[12] L.J. Hardwick, C.P. de León, Rechargeable Multi-Valent Metal-Air Batteries, Johnson Matthey Technol. Rev. 62 (2018) 134-149. doi:10.1595/205651318X696729.

[13] R.D. McKerracher, C. Ponce de Leon, R.G.A. Wills, A.A. Shah, F.C. Walsh, A Review of the Iron-Air Secondary Battery for Energy Storage, Chempluschem. 80 (2015) 323335. doi:10.1002/cplu.201402238.

[14] J. Omar, G. Posada, A.J.R. Rennie, S. Perez Villar, V.L. Martins, J. Marinaccio, A. Barnes, C.F. Glover, D.A. Worsley, P.J. Hall, Aqueous batteries as grid scale energy storage solutions, Renew. Sustain. Energy Rev. 68 (2016) 1174-1182. doi:10.1016/j.rser.2016.02.024. 
[15] L. Peng, Y. Zhu, D. Chen, R.S. Ruoff, G. Yu, Two-Dimensional Materials for BeyondLithium-Ion Batteries, Adv. Energy Mater. 6 (2016) 1600025.

doi:10.1002/aenm.201600025.

[16] V. Caramia, B. Bozzini, Materials science aspects of zinc-air batteries: A review, Mater. Renew. Sustain. Energy. 3 (2014) 28. doi:10.1007/s40243-014-0028-3.

[17] F. Cheng, J. Chen, Metal-air batteries: from oxygen reduction electrochemistry to cathode catalysts., Chem. Soc. Rev. 41 (2012) 2172-92. doi:10.1039/c1cs15228a.

[18] H. Arai, M. Hayashi, SECONDARY BATTERIES - METAL-AIR SYSTEMS | Overview (Secondary and Primary), Encycl. Electrochem. Power Sources. (2009) 347355. doi:10.1016/B978-044452745-5.00099-X.

[19] S.R. Narayan, A. Manohar, S. Mukerjee, Bi-Functional Oxygen Electrodes - Challenges and Prospects, Interface Mag. 24 (2015) 65-69. doi:10.1149/2.F06152if.

[20] Q. Li, R. Cao, J. Cho, G. Wu, Nanocarbon Electrocatalysts for Oxygen Reduction in Alkaline Media for Advanced Energy Conversion and Storage, Adv. Energy Mater. 4 (2014) 1301415. doi:10.1002/aenm.201301415.

[21] S. Park, Y. Shao, J. Liu, Y. Wang, Oxygen electrocatalysts for water electrolyzers and reversible fuel cells: status and perspective, Energy Environ. Sci. 5 (2012) 9331. doi:10.1039/c2ee22554a.

[22] C.R. Raj, A. Samanta, S.H. Noh, S. Mondal, T. Okajima, T. Ohsaka, U.S. Ozkan, C.M. Hadad, F. Idrees, I. Shakir, C. Cao, Y. Hou, R.R. Adzic, S.H. Joo, Emerging new generation electrocatalysts for the oxygen reduction reaction, J. Mater. Chem. A. 4 (2016) 11156-11178. doi:10.1039/C6TA03300H.

[23] Y. Zong, F.W.T. Goh, D. Wuu, X. Ge, T.S.A. Hor, A. Sumboja, B. Li, T. An, Z. Liu, Oxygen Reduction in Alkaline Media: From Mechanisms to Recent Advances of Catalysts, ACS Catal. 5 (2015) 4643-4667. doi:10.1021/acscatal.5b00524.

[24] Z.-L. Wang, D. Xu, J.-J. Xu, X.-B. Zhang, Oxygen electrocatalysts in metal-air batteries: from aqueous to nonaqueous electrolytes., Chem. Soc. Rev. 43 (2014) 7746-86. doi:10.1039/c3es60248f.

[25] D.U. Lee, P. Xu, Z.P. Cano, A.G. Kashkooli, M.G. Park, Z. Chen, Recent progress and perspectives on bi-functional oxygen electrocatalysts for advanced rechargeable metalair batteries, J. Mater. Chem. A. 4 (2016) 7107-7134. doi:10.1039/C6TA00173D.

[26] L. Osmieri, A.H.A. Monteverde Videla, M. Armandi, S. Specchia, Influence of different transition metals on the properties of $\mathrm{Me}-\mathrm{N}-\mathrm{C}(\mathrm{Me}=\mathrm{Fe}, \mathrm{Co}, \mathrm{Cu}, \mathrm{Zn})$ catalysts synthesized using SBA-15 as tubular nano-silica reactor for oxygen reduction reaction, Int. J. Hydrogen Energy. 41 (2016) 22570-22588. doi:10.1016/j.ijhydene.2016.05.223.

[27] Y. He, J. Zhang, G. He, X. Han, X. Zheng, C. Zhong, W. Hu, Y. Deng, Ultrathin $\mathrm{Co}_{3} \mathrm{O}$ 4 nanofilm as an efficient bifunctional catalyst for oxygen evolution and reduction reaction in rechargeable zinc-air batteries, Nanoscale. 9 (2017) 8623-8630. doi:10.1039/C7NR02385E.

[28] S. Guo, S. Zhang, L. Wu, S. Sun, Co/CoO Nanoparticles Assembled on Graphene for Electrochemical Reduction of Oxygen, Angew. Chemie Int. Ed. 51 (2012) 11770-11773. doi:10.1002/anie.201206152.

[29] Z. Wang, B. Li, X. Ge, F.W.T. Goh, X. Zhang, G. Du, D. Wuu, Z. Liu, T.S. Andy Hor, H. Zhang, Y. Zong, Co@ $\mathrm{Co}_{3} \mathrm{O}_{4} @$ PPD Core@bishell Nanoparticle-Based Composite as an Efficient Electrocatalyst for Oxygen Reduction Reaction, Small. 12 (2016) 2580 2587. doi:10.1002/smll.201503694. 
[30] S.K. Singh, V.M. Dhavale, S. Kurungot, Surface-Tuned Co3O4 Nanoparticles Dispersed on Nitrogen-Doped Graphene as an Efficient Cathode Electrocatalyst for Mechanical Rechargeable Zinc-Air Battery Application, ACS Appl. Mater. Interfaces. 7 (2015) 21138-21149. doi:10.1021/acsami.5b04865.

[31] A. Aijaz, J. Masa, C. Rösler, W. Xia, P. Weide, A.J.R. Botz, R.A. Fischer, W. Schuhmann, M. Muhler, Co@Co3O4 Encapsulated in Carbon Nanotube-Grafted Nitrogen-Doped Carbon Polyhedra as an Advanced Bifunctional Oxygen Electrode., Angew. Chem. Int. Ed. Engl. 55 (2016) 4087-91. doi:10.1002/anie.201509382.

[32] Z. Wang, S. Xiao, Z. Zhu, X. Long, X. Zheng, X. Lu, S. Yang, Cobalt-Embedded Nitrogen Doped Carbon Nanotubes: A Bifunctional Catalyst for Oxygen Electrode Reactions in a Wide pH Range, ACS Appl. Mater. Interfaces. 7 (2015) 4048-4055. doi:10.1021/am507744y.

[33] X. Han, G. He, Y. He, J. Zhang, X. Zheng, L. Li, C. Zhong, W. Hu, Y. Deng, T.-Y. Ma, Metal Air Batteries: Engineering Catalytic Active Sites on Cobalt Oxide Surface for Enhanced Oxygen Electrocatalysis, Adv. Energy Mater. 8 (2018) 1870043. doi:10.1002/aenm.201870043.

[34] A. Li, C. Wang, H. Zhang, Z. Zhao, J. Wang, M. Cheng, H. Zhao, J. Wang, M. Wu, J. Wang, Graphene supported atomic Co/nanocrystalline Co3O4 for oxygen evolution reaction, Electrochim. Acta. 276 (2018) 153-161. doi:10.1016/J.ELECTACTA.2018.04.177.

[35] A.H.A.A. Monteverde Videla, P. Stelmachowski, G. Ercolino, S. Specchia, Benchmark comparison of $\mathrm{Co} 3 \mathrm{O} 4$ spinel-structured oxides with different morphologies for oxygen evolution reaction under alkaline conditions, J. Appl. Electrochem. 47 (2017) 295-304. doi:10.1007/s10800-016-1040-3.

[36] P. Stelmachowski, A.H.A. Monteverde Videla, K. Ciura, S. Specchia, Oxygen evolution catalysis in alkaline conditions over hard templated nickel-cobalt based spinel oxides, Int. J. Hydrogen Energy. 42 (2017) 27910-27918. doi:10.1016/J.IJHYDENE.2017.06.034.

[37] C. Qian, X. Guo, W. Zhang, H. Yang, Y. Qian, F. Xu, S. Qian, S. Lin, T. Fan, Co3O4 nanoparticles on porous bio-carbon substrate as catalyst for oxygen reduction reaction, Microporous Mesoporous Mater. 277 (2019) 45-51. doi:10.1016/J.MICROMESO.2018.10.020.

[38] K. Artyushkova, A. Serov, S. Rojas-Carbonell, P. Atanassov, Chemistry of Multitudinous Active Sites for Oxygen Reduction Reaction in Transition MetalNitrogen-Carbon Electrocatalysts, J. Phys. Chem. C. 119 (2015) 25917-25928. doi:10.1021/acs.jpcc.5b07653.

[39] S. Zhao, B. Rasimick, W. Mustain, H. Xu, Highly durable and active Co3O4 nanocrystals supported on carbon nanotubes as bifunctional electrocatalysts in alkaline media, Appl. Catal. B Environ. 203 (2017) 138-145. doi:10.1016/j.apcatb.2016.09.048.

[40] S. Cai, Z. Meng, H. Tang, Y. Wang, P. Tsiakaras, 3D Co-N-doped hollow carbon spheres as excellent bifunctional electrocatalysts for oxygen reduction reaction and oxygen evolution reaction, Appl. Catal. B Environ. 217 (2017) 477-484. doi:10.1016/j.apcatb.2017.06.008.

[41] Y.-J. Wang, A. Li, D. Zhang, J. Zhang, B. Fang, D.P. Wilkinson, A. Ignaszak, L. Zhang, A Review of Carbon-Composited Materials as Air-Electrode Bifunctional Electrocatalysts for Metal-Air Batteries, Electrochem. Energy Rev. 1 (2018) 1-34. doi:10.1007/s41918-018-0002-3. 
[42] C. Alegre, A. Stassi, E. Modica, C. Lo Vecchio, A.S. Aricò, V. Baglio, Investigation of the activity and stability of Pd-based catalysts towards the oxygen reduction (ORR) and evolution reactions (OER) in iron-air batteries, RSC Adv. 5 (2015) 25424-25427. doi:10.1039/C4RA15578E.

[43] D. Sebastián, A.G. Ruíz, I. Suelves, R. Moliner, M.J. Lázaro, V. Baglio, A. Stassi, A.S. Aricò, Enhanced oxygen reduction activity and durability of Pt catalysts supported on carbon nanofibers, Appl. Catal. B Environ. 115-116 (2012) 269-275. doi:10.1016/j.apcatb.2011.12.041.

[44] D. Sebastián, C. Alegre, M.E. Gálvez, R. Moliner, M.J. Lázaro, A.S. Aricò, V. Baglio, Towards new generation fuel cell electrocatalysts based on xerogel-nanofiber carbon composites, J. Mater. Chem. A. 2 (2014) 13713. doi:10.1039/C4TA02108H.

[45] P.N. Ross, M. Sattler, The Corrosion of Carbon Black Anodes in Alkaline Electrolyte, J. Electrochem. Soc. 135 (1988) 1464. doi:10.1149/1.2096029.

[46] M.P. Gurrola, J. Gutiérrez, S. Rivas, M. Guerra-Balcázar, J. Ledesma-García, L.G. Arriaga, Evaluation of the corrosion of Sb-doped $\mathrm{SnO} 2$ supports for electrolysis systems, in: Int. J. Hydrogen Energy, Pergamon, 2014: pp. 16763-16770. doi:10.1016/j.ijhydene.2014.02.156.

[47] V. Ávila-Vázquez, M. Galván-Valencia, J. Ledesma-García, L.G. Arriaga, V.H. CollinsMartínez, C. Guzmán-Martínez, I.L. Escalante-Garcia, S.M. Durón-Torres, Electrochemical performance of a Sb-doped $\mathrm{SnO} 2$ support synthesized by coprecipitation for oxygen reactions, J. Appl. Electrochem. 45 (2015) 1175-1185. doi:10.1007/s10800-015-0876-2.

[48] S. Pérez-Rodríguez, D. Sebastián, M.J. Lázaro, E. Pastor, Stability and catalytic properties of nanostructured carbons in electrochemical environments, J. Catal. 355 (2017) 156-166. doi:10.1016/J.JCAT.2017.09.019.

[49] B. Zhang, F. Kang, J.-M. Tarascon, J.-K. Kim, Recent advances in electrospun carbon nanofibers and their application in electrochemical energy storage, Prog. Mater. Sci. 76 (2016) 319-380. doi:10.1016/J.PMATSCI.2015.08.002.

[50] S. Peng, L. Li, J. Kong Yoong Lee, L. Tian, M. Srinivasan, S. Adams, S. Ramakrishna, Electrospun carbon nanofibers and their hybrid composites as advanced materials for energy conversion and storage, Nano Energy. 22 (2016) 361-395. doi:10.1016/J.NANOEN.2016.02.001.

[51] C. Alegre, C. Busacca, O. Di Blasi, V. Antonucci, A.S. Aricò, A. Di Blasi, V. Baglio, A combination of $\mathrm{CoO}$ and $\mathrm{Co}$ nanoparticles supported on electrospun carbon nanofibers as highly stable air electrodes, J. Power Sources. 364 (2017) 101-109. doi:10.1016/j.jpowsour.2017.08.007.

[52] C. Alegre, E. Modica, A. Di Blasi, O. Di Blasi, C. Busacca, M. Ferraro, A.S. Aricò, V. Antonucci, V. Baglio, NiCo-loaded carbon nanofibers obtained by electrospinning: Bifunctional behavior as air electrodes, Renew. Energy. 125 (2018). doi:10.1016/j.renene.2018.02.089.

[53] C. Alegre, S. Siracusano, E. Modica, A.S. Aricò, V. Baglio, Titanium-tantalum oxide as a support for Pd nanoparticles for the oxygen reduction reaction in alkaline electrolytes, Mater. Renew. Sustain. Energy. 7 (2018) 8. doi:10.1007/s40243-018-0114-z.

[54] R.D. McKerracher, C. Alegre, V. Baglio, A.S. Aricò, C. Ponce de León, F. Mornaghini, M. Rodlert, F.C. Walsh, A nanostructured bifunctional Pd/C gas-diffusion electrode for metal-air batteries, Electrochim. Acta. 174 (2015) 508-515. doi:10.1016/j.electacta.2015.06.001. 
[55] S. Siracusano, N. Van Dijk, E. Payne-Johnson, V. Baglio, A.S. Aricò, Nanosized IrOx and $\mathrm{IrRuOx}$ electrocatalysts for the $\mathrm{O} 2$ evolution reaction in PEM water electrolysers, Appl. Catal. B Environ. 164 (2015) 488-495. doi:10.1016/j.apcatb.2014.09.005.

[56] V. Ivanov, J.B. Nagy, P. Lambin, A. Lucas, X.F.X.B. Zhang, X.F.X.B. Zhang, D. Bernaerts, G. Van Tendeloo, S. Amelinckx, J. Van Landuyt, The study of carbon nanotubules produced by catalytic method, Chem. Phys. Lett. 223 (1994) 329-335. doi:10.1016/0009-2614(94)00467-6.

[57] J.L. Gautier, E. Rios, M. Gracia, J.F. Marco, J.R. Gancedo, Characterisation by X-ray photoelectron spectroscopy of thin $\mathrm{MnxC0} 3-\mathrm{xO} 4(1 \geq \mathrm{x} \geq 0)$ spinel films prepared by lowtemperature spray pyrolysis, Thin Solid Films. 311 (1997) 51-57. doi:10.1016/S00406090(97)00463-X.

[58] S. Abouali, M. Akbari Garakani, B. Zhang, H. Luo, Z.L. Xu, J.Q. Huang, J. Huang, J.K. $\mathrm{Kim}, \mathrm{Co} 3 \mathrm{O} 4$ /porous electrospun carbon nanofibers as anodes for high performance Liion batteries, 2 (2014) 16939-16944. doi:10.1039/c4ta03206c.

[59] H. Wu, G. Wu, Y. Ren, L. Yang, L. Wang, X. Li, $\mathrm{Co}^{2+} / \mathrm{Co}^{3+}$ ratio dependence of electromagnetic wave absorption in hierarchical $\mathrm{NiCo}_{2} \mathrm{O}_{4}-\mathrm{CoNiO}_{2}$ hybrids, J. Mater. Chem. C. 3 (2015) 7677-7690. doi:10.1039/C5TC01716E.

[60] R. Gao, Z. Li, X. Zhang, J. Zhang, Z. Hu, X. Liu, Carbon-Dotted Defective CoO with Oxygen Vacancies: A Synergetic Design of Bifunctional Cathode Catalyst for $\mathrm{Li}_{-}-\mathrm{O}_{2}$ Batteries, ACS Catal. 6 (2016) 400-406. doi:10.1021/acscatal.5b01903.

[61] L. Xu, Q. Jiang, Z. Xiao, X. Li, J. Huo, S. Wang, L. Dai, Plasma-Engraved $\mathrm{Co}_{3} \mathrm{O}_{4}$ Nanosheets with Oxygen Vacancies and High Surface Area for the Oxygen Evolution Reaction, Angew. Chemie Int. Ed. 55 (2016) 5277-5281. doi:10.1002/anie.201600687.

[62] C. Lo Vecchio, A.S. Aricò, G. Monforte, V. Baglio, EDTA-derived CoNC and FeNC electro-catalysts for the oxygen reduction reaction in acid environment, Renew. Energy. 120 (2018) 342-349. doi:10.1016/J.RENENE.2017.12.084.

[63] L. Zhang, Z. Su, F. Jiang, L. Yang, J. Qian, Y. Zhou, W. Li, M. Hong, Highly graphitized nitrogen-doped porous carbon nanopolyhedra derived from ZIF-8 nanocrystals as efficient electrocatalysts for oxygen reduction reactions, Nanoscale. 6 (2014) 6590-6602. doi:10.1039/C4NR00348A.

[64] J. Zhang, M. Chen, L. Zhu, Activation of persulfate by $\mathrm{Co}_{3} \mathrm{O}_{4}$ nanoparticles for orange G degradation, RSC Adv. 6 (2016) 758-768. doi:10.1039/C5RA22457H.

[65] A. Di Blasi, C. Busacca, O. Di Blasi, N. Briguglio, V. Antonucci, Synthesis and Characterization of Electrospun Nickel-Carbon Nanofibers as Electrodes for Vanadium Redox Flow Battery, J. Electrochem. Soc. 165 (2018) A1478-A1485. doi:10.1149/2.1081807jes.

[66] H. Bin Yang, J. Miao, S.-F. Hung, J. Chen, H.B. Tao, X. Wang, L. Zhang, R. Chen, J. Gao, H.M. Chen, L. Dai, B. Liu, Identification of catalytic sites for oxygen reduction and oxygen evolution in N-doped graphene materials: Development of highly efficient metal-free bifunctional electrocatalyst, Sci. Adv. 2 (2016) e1501122. doi:10.1126/sciadv.1501122.

[67] V.A. Golovin, N.V. Maltseva, E.N. Gribov, A.G. Okunev, New nitrogen-containing carbon supports with improved corrosion resistance for proton exchange membrane fuel cells, Int. J. Hydrogen Energy. 42 (2017) 11159-11165. doi:10.1016/J.IJHYDENE.2017.02.117.

[68] S. Pérez-Rodríguez, E. Pastor, M.J. Lázaro, Electrochemical behavior of the carbon black Vulcan XC-72R: Influence of the surface chemistry, Int. J. Hydrogen Energy. 43 
(2018) 7911-7922. doi:10.1016/J.IJHYDENE.2018.03.040.

[69] D. Yu, C. Xu, Y. Su, D. Liu, X. He, Nitrogen-doped graphene aerogels-supported cobaltosic oxide nanocrystals as high-performance bi-functional electrocatalysts for oxygen reduction and evolution reactions, J. Electroanal. Chem. 787 (2017) 46-54. doi:10.1016/J.JELECHEM.2017.01.034.

[70] S. Mao, Z. Wen, T. Huang, Y. Hou, J. Chen, High-performance bi-functional electrocatalysts of 3D crumpled graphene-cobalt oxide nanohybrids for oxygen reduction and evolution reactions, Energy Environ. Sci. 7 (2014) 609-616. doi:10.1039/C3EE42696C. 